\title{
Things You Should Care About in the New Patent Statute ${ }^{1}$
}

\author{
Mark A. Lemley ${ }^{2}$
}

\section{False Marking}

Change: Allows virtual marking by pointing to a web site containing the patents. Provides that marking with expired patents does not violate the law. Provides that only the United States can sue for the $\$ 500$ statutory penalty. Permits private actions only to recover damages from those who suffer "competitive injury."

Effective Date: Immediate and retroactive to all pending cases.

Implication: This will effectively eliminate false marking suits. Only competitors will be able to bring a private suit, and only if they can prove actual injury. The statute may have the effect of encouraging the deliberate marking of expired patents.

\section{Tax Strategy Patents}

Change: "Any strategy for reducing, avoiding, or deferring tax liability, whether known or unknown at the time of the invention, shall be deemed insufficient to differentiate a claimed invention from the prior art." Does not apply to patents covering preparation of tax returns or to patents covering methods or systems "used solely for financial management."

Effective Date: Immediate, and applies to existing patents.

Ambiguity: The intent of the statute seems to be to render tax dodge strategies unpatentable. But the language arguably sweeps either too broadly or too narrowly to achieve that goal. If it is merely the fact that the strategy itself is not considered part of the prior art, the strategy could still be patented if coupled with, say, a computer-readable medium in a way that had never been done before. On the other hand, if the statute is read to provide that patents that include such a strategy are unpatentable, it might cover any number of business methods or even technical inventions that can also serve the purpose of reducing or avoiding tax liability.

1 Well, if you're a patent lawyer, anyway. Things litigators should care about are highlighted.

2 William H. Neukom Professor, Stanford Law School; partner, Durie Tangri LLP. 
Implication: Some existing patents will be invalid (including possibly some that don't immediately strike the reader as being tax dodges).

\section{Patenting Humans}

Change: PTO cannot issue patents "directed to or encompassing a human organism."

Effective Date: Immediate; retroactive to existing applications (but not existing patents).

Ambiguity: does "encompassing" cover biotechnology patents that claim methods of treatment? Does a "human organism" include a fetus or a stem cell?

Implication: Not much, absent a very broad reading of "encompassing." The PTO wasn't issuing such patents anyway. Might prevent patents covering embryonic stem cells, depending on interpretation.

\section{PTO Fees}

Change: The PTO is given fee-setting authority. Fees can only be set to recover "aggregate costs" for each side of the PTO (patents or trademarks). New "micro entities" (which don't make more than three times median household income and haven't filed more than four other patents, or which happen to be universities) get a $75 \%$ fee reduction.

Effective Date: September 16, 2011. Sunsets on September 16, 2018.

Implication: Fees may increase (except for micro-entities). PTO may be better funded and may process applications more quickly, more thoroughly, or both.

\section{PTO Funding}

Change: Provides that PTO fees must be segregated in a special fund and can be used only for PTO expenses. Prevents the PTO from diverting money from the trademark side to the patent side or vice versa.

Effective Date: October 1, 2011. 
Implication: Congress can restrain PTO expenditures, but can't take the money away from the PTO for other purposes. Prevents direct fee diversion, but may or may not be effective in preventing back-door methods of withholding PTO fees.

\section{Best Mode}

Change: Eliminates best mode as a ground for invalidity, unenforceability, or cancellation by the PTO. Appears to preserve it as a ground for PTO examination.

Effective Date: Applies to suits or reexamination proceedings beginning September 16, 2011.

Implication: Effectively eliminates best mode. While it remains in the statute, and the PTO could nominally police compliance with the requirement, it has never done so in the past, and there is no reason to think it will in the future.

\section{Joinder}

Change: Forbids parties or courts from joining multiple defendants or consolidating cases against those defendants unless there are common issues of fact or the cases arise out of the same transaction or occurrence. The fact that they are accused of infringing the same patent is not enough.

Effective Date: Applies to all lawsuits filed on or after September 16, 2011.

Implication: Multi-defendant patent litigation will become a thing of the past. The number of patent cases filed will likely increase significantly. Patent plaintiff costs will increase, and patentees suing multiple defendants will face multiple assessments of validity, each with potential collateral estoppel effect.

\section{Exclusive Jurisdiction in Federal Court}

Change: Extends exclusive federal court jurisdiction to any "claim for relief arising under" the patent statute, even if the original cause of action does not arise under the patent statute. This includes patent arguments raised as counterclaims. Extends Federal Circuit jurisdiction to patent counterclaims, even if the original cause of action does not arise under the patent statute.

Effective Date: Applies to any lawsuit filed beginning September 16, 2011. 
Ambiguity: What is a "claim for relief"? Does a defense count if it is asserted in declaratory judgment form?

Implication: Reverses Holmes Group and consolidates appeals from patent cases in the Federal Circuit. May move some license or malpractice cases from state to federal court, depending on how the term "claim for relief" is interpreted. Note that the statute does not extend exclusive federal jurisdiction to issues that require resolution of a question of patent law.

\section{Prior User Rights}

Change: Extends existing prior user rights, now applying only to business method patents, to "a process, or a machine, manufacture, or composition of matter used in a manufacturing or other commercial process." Does not apply to patents owned by a university at the time the prior use was made.

Effective Date: Applies to any patent issued after September 16, 2011.

Ambiguity: Some have read the definition to reach all sorts of patent claims, but the effect of the language seems to be to limit its reach to process claims and to things used in an internal manufacturing process, not to goods actually sold by the defendant.

Implication: This is a potentially significant defense for companies that develop ideas for internal manufacturing and keep them as trade secrets. The defense is limited in a number of ways, and is not tradable. The early effective date means that while it will not apply to existing cases, it could start being litigated quite soon.

\section{Inter Partes Reexam}

Change: Provides that inter partes reexams can be instituted only after the post-grant opposition window has closed. Raises the standard for opening an inter partes reexam to require that the initial petition "shows that there is reasonable likelihood that the petitioner would prevail with respect to at least one of the claims challenged." Refusal to open a proceeding is unappealable. Can't seek inter partes reexam if you have already DJ'd. Stays later-filed DJs by the same party unless the patentee counterclaims for infringement. The PTO can consolidate co-pending proceedings. Inter partes reexams go to a three-judge 
panel of the new Patent Trial and Appeal Board, not to the examiner corps.

Parties can settle inter partes reexams, but estoppel effect disappears if they do.

Effective Date: Immediate as to the higher threshold for instituting an inter partes reexam; applies to any reexams instituted after date of enactment. Remaining provisions take effect one year after enactment, and apply to all patents, whenever issued.

Implication: (1) It will be substantially harder to obtain inter partes review.

(2) The stay provision is weakened, so that inter partes reexam and litigation can coexist as long as the patentee is charging infringement, but those who have already DJ'd in litigation are forbidden from filing an inter partes reexam. Note that because this provision applies only to those who "institute a civil action" claiming invalidity, a defendant in an infringement suit may be able to both defend on invalidity grounds and file an inter partes reexam.

(3)The move from the examining corps to the Board may mean that inter partes reexams are taken more seriously in the PTO.

\section{Special Post-Grant Review for Business Methods}

Change: Adopts the new post-grant review procedure described below, but applies it to existing business method patents issued more than nine months ago, and allows all forms of prior art. To invoke the business method review, a petitioner must have been sued for infringing the patent or "charged" with infringing the patent. Courts may decide whether to stay such proceedings, but the statute creates a right of de novo interlocutory review of the stay decision.

Effective Date: Effective September 16, 2012, and applies to existing patents as of that date. Sunsets on September 16, 2019.

Ambiguity: (1) The definition of a "covered business method patent" includes "a method or corresponding apparatus for performing data processing or other operations used in the practice, administration, or management of a financial product or service" but excludes "patents for technological inventions." The PTO is to promulgate regulations "for determining whether a patent is for a technological invention."

(2) It is not clear what "charging" someone with infringement means, though it apparently means something other than filing suit. 
(3) The prior art definition is curious, and seems to largely track existing 102(a) and (b) but without using the same language.

Implication: This will be a test-bed for post-grant review in a small set of cases. It may also produce Federal Circuit decisions on the issue of stays pending PTO administrative review.

\section{Prior Art Submission}

Change: Any party can submit prior art patents or publications to the PTO within six months after publication or before the first rejection.

Effective Date: September 17, 2012. As of that date applies to patents and applications whenever filed.

Implication: Opens the door for programs like peer-to-patent that involve pre-issuance prior art submission.

13. Inventorship

Change: Allows companies to file a patent in an inventor's name even if the inventor refuses to sign the oath. Allows correction of inventorship in the PTO or in court whether or not the incorrect inventorship was the result of deceptive intention, as part of the removal of all references to deceptive intent in the statute.

Effective Date: Applies to patents filed after September 16, 2012. Deceptive intent provisions apply to proceedings commenced after September 16, 2012.

Implication: (1) Inventorship will essentially become irrelevant as a ground of invalidity, because it can always be corrected. That may make it irrelevant for inequitable conduct purposes too under the Therasense but-for standard.

(2) The fact that an employee need not sign an oath to file a patent might call into question the doctrine of assignor estoppel in those cases.

\section{Supplemental Examination to Avoid Inequitable Conduct}


Change: Patentee can submit its patent for supplemental examination, which acts as a reexamination except that it is not limited to prior art patents and publications. This reexamination can cleanse prior inequitable conduct. To do so, the supplemental examination must be completed before the patentee files suit, and must be initiated before any DJ action that pleads the inequitable conduct with particularity.

Effective Date: September 17, 2012. As of that date applies to patents and applications whenever filed.

Implication: Supplemental examination may not add much to the law of inequitable conduct after Therasense, both because IC will be very hard to prove and because it effectively implements a but-for standard, just as Therasense does. But patentees may still want to use the supplemental examination, because they can cleanse their past misbehavior in an ex parte setting, rather than in a court proceeding.

\section{Advice of Counsel and Inducement}

Change: Provides that failure to obtain or to present advice of counsel can't be used as evidence of willful infringement or inducement.

Effective Date: Not specified, which means that it applies only to patents issued on or after September 16, 2012. Note that this significant delay is probably unintentional.

Implication: No immediate change in the law. No substantive change in the law of willfulness, which already provides this, though it clarifies that courts should not allow in evidence of failure to rely on advice of counsel. Will eventually reverse Broadcom, in which the Federal Circuit suggested that failure to obtain advice of counsel could be evidence of inducement.

\section{First Inventor to File}

Change: In priority disputes, priority is given to the first inventor to file an application, or to the first inventor to disclose the invention to the public, assuming they then file within a year. Swearing behind a reference is eliminated.

Effective Date: Applies to applications with effective filing dates after March 16, 2013. 
Ambiguity: There is some disagreement over the meaning of the word "disclosure" that creates the one-year grace period. Senate legislative history and traditional use of the term in patent cases would apply it to any form of prior art, such as a public use or a sale. That is the better view. But some have argued that it covers only published disclosures.

Implication: File early. It is possible, though unlikely, that a grace period will be lost if based on sales or public uses. Note that the grace period applies only to the patentee's disclosures, and those made by people who got the invention from the patentee, not to third party art.

\section{Changes in the Definition of Prior Art}

Change: Section $102(\mathrm{~g})$ is abolished as a source of prior art. "Known or used by others" is abolished as a source of prior art. "Public use" and "on sale" are now prior art regardless of where in the world they occur. There is no 1-year grace period as to third-party prior art unless that art was derived from the patentee, or unless the patentee disclosed first. "Otherwise available to the public" is added as a source of prior art.

Effective Date: Applies to applications with effective filing dates after March 16, 2013.

Ambiguity: Some have argued that "otherwise available to the public" should be construed to limit public use and on sale to require that those be available to the public as well. Inherent is not expressly identified (but then, it isn't in the 1952 Act either).

Implication: More conduct will be prior art, both because of the worldwide scope of sales and public uses and because there is no third party grace period. The elimination of swearing behind means that patentees will find it harder to defeat prior art once identified. But the elimination of $102(\mathrm{~g})(2)$ prior art will make anticipation somewhat less likely. Inventors are encouraged either to file or to disclose early, since disclosure will give them a one-year grace period even against third party art. [This grace period can be based not only on the inventor's actual disclosure, but also the disclosure of another subject to the same ownership or to a joint research agreement. This is similar to the current operation of section 103(c)]. 


\section{Derivation Proceedings}

Change: Interference proceedings are replaced with "derivation proceedings" in cases in which the applicant claims that a competing application or prior disclosure was derived from the applicant's own work.

Effective Date: Applies to applications with effective filing dates after March 16, 2013.

Implication: This provision effectively replaces 102(f); it remains illegal to obtain a patent based on an idea you took from someone else, even if you file your application first. While some have suggested that this provision eliminates 102(f) prior art as a basis for obviousness, the derivation proceeding seems broad enough to encompass obvious variants of information obtained from another.

\section{Modifications to Obviousness}

Change: Section 103(b), dealing with biotechnology inventions, is repealed. Obviousness is now tested as of the effective filing date of the patent, not the date of invention.

Effective Date: Applies to applications with effective filing dates after March 16, 2013.

Implication: Not much. Section 103(b) was rarely used. The focus on the effective filing date rather than the date of invention could make findings of obviousness marginally more likely, as it changes the level of knowledge of the PHOSITA.

\section{Post-Grant Opposition}

Change: Creates a new administrative review procedure in addition to reexamination.

Opposers can raise any ground of invalidity. Oppositions must be filed within 9 months after the grant of a patent. Threshold for instituting opposition in the PTO is that the initial filing demonstrates that "it is more likely than not that at least one of the claims is unpatentable" or that the petition raises a novel, important, and unsettled legal question. Refusal to open a proceeding is unappealable. Can't seek post-grant opposition if you have already DJ'd. Stays later-filed DJs by the same party unless the patentee counterclaims for infringement. Estoppel provisions the same as inter partes reexam. Opposer carries burden of showing invalidity by a preponderance of the evidence. Postgrant oppositions go to a three-judge panel of the new Patent Trial and Appeal 
Board, not to the examiner corps. Parties can settle post-grant oppositions, but estoppel effect disappears if they do.

Effective Date: Applies only to patents issued under the new first-to-file rules.

Ambiguity: During the several-year period in transition from first to file, neither inter partes reexam nor post-grant opposition appear to be available during the first nine months of a patent term. That omission seems to be inadvertent, a result of the complex effective date provisions.

Implication: Post-grant opposition and litigation can coexist as long as the patentee is charging infringement, but those who have already DJ'd in litigation are forbidden from filing an opposition. Note that because this provision applies only to those who "institute a civil action" claiming invalidity, a defendant in an infringement suit may be able to both defend on invalidity grounds and file an opposition. 